\title{
RELATIONSHIP BETWEEN LEARNING MOTIVATION, USE OF LEARNING SOURCES AND ATTENTION OF PARENTS WITH MATHEMATICS RESULTS OF STUDENTS MTS NEGERI GODEAN
}

\author{
Riska Febriyannti Utamia ${ }^{a}$, Widayati ${ }^{b}$ \\ Program Studi Pendidikan Matematika Universitas Ahmad Dahlan \\ Jalan Ring Road Selatan, Tamanan, Banguntapan, Bantul Yogyakarta \\ ariska_tgs@yahoo.co.id, bummunabilah67@gmail.com
}

\begin{abstract}
The low students learning motivation, students do not use learning resources well, and low of parents' attention to children's learning activities were related to students mathematics learning outcomes. This study aims to determine the presence or absence of a positive relationship between and significant relationship between learning motivation, use of learning resources, and parents' attention with the result of mathematics learning outcomes in students class VII on odd semester at MTs Negeri Godean Academic Year of 2015/2016. The population in this study was all students of class VII on odd semester at MTs Negeri Godean Academic Year of 2015/2016 consists of 4 class. While the sample being picked class VII B and test class VII A as a study sample with a random sampling technique to the class. Data were collected by a questionnaire test and methods test. Test research instruments used are the validity test, reliability test, and different power test. The prerequisite test used normally tests, linearity and independent test. Analysis of data using product-moment correlation analysis and linear regression analysis. The result showed that there was a positive and significant correlation between learning motivation, use of learning resources and parent attention with mathematic learning outcomes, multiple correlation coefficient $(R) 0,823$ with a regression equation $\hat{Y}=-33,384+0,427 X_{1}+$ $0,487 X_{2}+0,288 X_{3}$, at the 5\% significance level, obtained $F_{\text {count }}$ at 19,716 and $F_{\text {table }}$ at 2,95 means $F_{\text {count }} \geq F_{\text {table }}$. The percentage relative contribution of learning motivation $42,71 \%$, the relative contribution on use of learning $36,33 \%$, and the relative contribution on parents attention $20,97 \%$ and then the effective contribution of learning motivation $28,99 \%$, the effective contribution of the use of learning outcomes $24,65 \%$, and the effective contribution of parents attention $14,23 \%$.
\end{abstract}

Keywords: Motivation Learning, Use of Learning Resources, Parents Attention, Learning Outcomes.

\section{INTRODUCTION}

Education has an important role to ensure the development and survival of a nation because education is a vehicle to improve and develop the quality of human resources in the face of global competition. Education for human life is an absolute necessity that must be fulfilled throughout life. Education is not only a means to convey knowledge, but a means to provide changes to a better life pattern. Education is expected to be able to form students who think logically, critically, creatively and systematically, so that they can solve problems by developing the potential for this way of thinking to be developed through mathematics lessons. Mathematics can be one of the means to improve the ability to face life's challenges in solving problems.

The success of student learning in terms of learning outcomes is influenced by two factors, namely factors originating from within (internal) and factors originating from outside of students (external). Internal factors that influence include physical factors, intelligence/intelligence, discipline, interest, talent, and motivation. While external factors that influence include parents' attention, learning environment, learning facilities, and learning resources. Student success at school is characterized by high learning outcomes. During this time there are several problems in learning mathematics, one of which is the lack of student motivation in learning mathematics. Motivation can be said as the overall driving force within students that makes students carry out learning activities that ensure the continuity of learning activities and give direction to learning activities. A student who has high learning motivation will always try to achieve good learning outcomes, with perseverance, perseverance, pleasure and study hard, and solve practice questions. 
The provision of learning resources is something that needs to be considered in the school environment to help improve learning outcomes. Learning resources are materials that can be used and used to help teachers and students achieve learning goals. The main learning resources that can be used include printed learning resources (books, student worksheets, worksheets, modules, etc.), electronic learning resources (audio, audiovisual, internet, etc.), and the surrounding environment such as social, natural and cultural. Learning resources that are generally available in schools are books and worksheets and can be meaningful if used effectively by students and teachers well.

The main influence of life, growth, and development of students in the family, namely parents as the main responsibility. It is suspected that parents' attention is needed to improve mathematics learning outcomes. As for the attention of parents to learning outcomes including providing children's learning facilities such as places to learn, learning equipment, and learning resources. Also, parents' attention can be in the form of supervising children's learning activities, managing children's learning schedules, and helping the child's learning difficulties. Although in reality there are still many parents who neglect their obligations to always pay attention to their children's learning development.

Learning outcomes, in essence, are a reflection of learning efforts, in general, the more often students learn mathematics, the more understanding or understanding of what is meant in mathematical concepts or theories, so the more optimal the results obtained. In learning mathematics, highly motivated children, use learning resources well and get the attention of parents towards mathematics are thought to be able to show an understanding of these lessons so that their learning outcomes will improve. Based on interviews with several students and mathematics teachers Mr. Suretno S.Pd at MTs Negeri Godean in August 2015, mathematics is one of the subjects that students avoid, because mathematics is a difficult subject for them, so it affects the learning outcomes of mathematics. This can be seen from the average value of midterm mathematics tests in grade VII of Odd Semester MTs Negeri Godean which can be seen in the following table.

Table 1. Middle Deuteronomy Mathematics Grade VII Grade Odd Semester MTs Negeri Godean

\begin{tabular}{|c|c|c|c|c|c|c|}
\hline No. & class & MCC & mean & $\begin{array}{c}\text { Complet } \\
\mathbf{e}(\%)\end{array}$ & $\begin{array}{c}\text { Not } \\
\text { complete } \\
\text { yet }(\%)\end{array}$ & $\begin{array}{c}\text { Amount } \\
\text { of } \\
\text { students }\end{array}$ \\
\hline 1. & VII A & 75 & 56,75 & 12,5 & 87,5 & 32 \\
\hline 2. & VII B & 75 & 72,37 & 56,25 & 43,75 & 32 \\
\hline 3. & VII C & 75 & 69,93 & 28,125 & 71,875 & 32 \\
\hline 4. & VII D & 75 & 76,37 & 68,75 & 31,25 & 32 \\
\hline
\end{tabular}

(Source: MTs Negeri Godean)

Based on observations at MTs Negeri Godean, some students did not take the math seriously, this was due to students' lack of motivation to study. So that almost every beginning of the meeting the teacher must give an extra appeal to be more serious in learning. At the end of the meeting, the teacher always evaluates students by reminding them to keep learning at home, the material that has been learned at school is studied again at home. Based on observations about the use of learning resources, students do not optimize learning resources properly. Students have been facilitated by the school with a mathematics textbook but only learned during the lesson students tend not to want to read and study it again. Based on information from several grade VII students of MTs Negeri Godean, parents pay less attention to children's learning activities such as tests, assignments, mastery of the material at school. Information from the BK Gangsan MTs BK teachers namely parents of Godean MTs Sleman District students have different levels of education, most have high school education and below and the majority earn a living as laborers and farmers. Most parents pay less attention to their children's learning at home, parents fully give up their children's education at school.

The purpose of this study is as follows: 
1. To find out whether or not there is a positive and significant relationship between learning motivation and mathematics learning outcomes for Grade VII students of MTs Negeri Godean, Sleman Regency Academic Year 2015/2016.

2. To find out whether or not there is a positive and significant relationship between the use of learning resources with mathematics learning outcomes for Grade VII students of MTs Negeri Godean, Sleman Regency Academic Year 2015/2016.

3. To find out whether or not there is a positive and significant relationship between parents' attention and mathematics learning outcomes for Grade VII students of MTs Negeri Godean, Sleman Regency Academic Year 2015/2016.

4. To find out whether or not there is a positive and significant relationship between motivation and use of learning resources with mathematics learning outcomes of Grade VII students of MTs Negeri Godean, Sleman Regency Academic Year 2015/2016.

5. To find out whether or not there is a positive and significant relationship between learning motivation and parents' attention with mathematics learning outcomes of Grade VII students of MTs Negeri Godean, Sleman Regency Academic Year 2015/2016.

6. To find out whether or not there is a positive and significant relationship between the use of learning resources and parental attention with mathematics learning outcomes for Grade VII students of MTs Negeri Godean, Sleman Regency Academic Year 2015/2016.

7. To find out whether or not there is a positive and significant relationship between learning motivation, use of learning resources, and parents' attention to mathematics learning outcomes of Grade VII students of MTs Negeri Godean, Sleman Regency Academic Year 2015/2016.

\section{METHODS}

This research is classified as quantitative research. This research was carried out in MTs Negeri Godean, Sleman Regency. Research time in odd semester 2015/2016 academic year. According to Sugiyono (2012b: 61) "population is a generalization area consisting of objects or subjects that have certain qualities and characteristics determined by researchers to be studied and then drawn conclusions". The population in this study were all students of class VII Odd Semester Mts Negeri Godean Sleman Regency Academic Year 2015/2016. The classes are Class VII A, VII B, VII C, and VII D, all classes are homogeneous because they are arranged randomly. According to Sugiyono (2012b: 62), "the sample is a portion of the number and characteristics possessed by the population". In this study, samples were taken 1 class randomly, using a random sampling technique for classes without regard to strata in the population. Sampling was done by lottery class, obtained class VII B as a research sample class with a total of 32 students.

In this study consists of 4 variables consisting of 3 independent variables and 1 dependent variable, including independent variables, namely motivation to learn (X1), use of learning resources (X2), parents' attention (X3). While the dependent variable is the learning outcomes of mathematics (Y). This study uses two data collection techniques in data collection, namely test and questionnaire techniques. According to Arikunto, Suharsimi (2009: 53) states that a test is a tool or procedure used to find out or measure something in an atmosphere, through rules that have been determined. The test used to collect data using the dependent variable is the learning outcomes of grade VII mathematics. According to Sugiyono (2009a: 142) that questionnaire or questionnaire is a data collection technique that is done by giving a set of questions or written statements to respondents to answer. The questionnaire method in this study was used to obtain data on learning motivation, the use of learning resources, and attentive parents. The data analysis technique in this research is descriptive data analysis. For the prerequisite test analysis using the hypothesis test with the requirements to meet the normality test, linearity test and independent test. Next hypothesis testing uses regression analysis. Regression analysis is a mathematical instrument that states the functional relationship between the independent variable and the dependent variable. 


\section{RESULTS AND DISCUSSION}

The first hypothesis test result is that there is a positive and significant relationship of learning motivation with learning outcomes in mathematics. with a simple correlation coefficient $(r)=0.7099$, at a significant level of 5\%. This can be explained through linear relationships $\widehat{Y}=5,9704+0,7431 X_{1}$. This means that every increase of one unit $\mathrm{X}_{1}$ results in 0.7431 increase in $\mathrm{Y}$, in other words, the higher the motivation to learn, the higher the mathematics learning outcomes. From the results of this calculation, it can be seen that increasing motivation to learn mathematics student learning outcomes will be even better, and vice versa.

The second hypothesis test result is that there is a positive and significant relationship between the use of learning resources with mathematics learning outcomes, with a simple correlation coefficient $(\mathrm{r})=0.6595$, at a significant level of $5 \%$. This can be explained through linear relationships $\hat{Y}=$ $-4,0393+0,8602 X_{2}$. This means that each increase in one unit of $X_{2}$ results in a 0.8602 increase in $Y$, in other words, if the use of learning resources is utilized properly, then the results of learning mathematics will increase. From the results of this calculation, it can be seen that by utilizing and using learning resources properly, student mathematics learning outcomes will be even better, and vice versa.

The third hypothesis test results are that there is a positive and significant relationship of parents' attention to mathematics learning outcomes, with a simple correlation coefficient $(r)=0.6814$ at a significant level of $5 \%$. This can be explained through a linear relationship $\hat{Y}=-14,7875+$ $0,9406 X_{3}$. This means that every increase of one unit of $X_{3}$ results in a 0.9406 increase in $\mathrm{Y}$, in other words, if the parents' attention is high towards children's learning activities, the mathematics learning outcomes will increase. From the results of this calculation, it can be seen that with parents' attention to their children's learning activities, student mathematics learning outcomes will be even better, and vice versa.

The fourth hypothesis test results are that there is a positive and significant relationship of learning motivation and the use of learning resources with mathematics learning outcomes, with a multiple correlation coefficient $(\mathrm{R})=0.8111$ at a significant level of $5 \%$. This can be explained through linear relationships $\hat{Y}=-24,7388+0,5475 X_{1}+0,5668 X_{2}$. This means that every increase of one unit $\mathrm{X} 1$ results in a 0.5475 increase in $\mathrm{Y}$ and every increase in one unit $\mathrm{X}_{2}$ results in a 0.5668 increase in $\mathrm{Y}$, in other words, if the motivation to learn and use of learning resources is high, the mathematical learning outcomes will increase. From the results of these calculations, it can be seen that by increasing learning motivation and the use of learning resources in mathematics subjects, student mathematics learning outcomes will be even better, and vice versa.

The fifth hypothesis test results are that there is a positive and significant relationship of learning motivation and parents' attention with mathematics learning outcomes, with a multiple correlation coefficient $(\mathrm{R})=0.7713$ at a significant level of $5 \%$. This can be explained through linear relationships $\hat{Y}=-17,0504+0,4806 X_{1}+0,5129 X_{2}$. This means that every increase of one unit $X_{1}$ results in a 0.4806 increase in $\mathrm{Y}$ and every increase in one unit $\mathrm{X}_{3}$ results in a 0.5129 increase in $\mathrm{Y}$, in other words, if the motivation of learning and parents' attention is high, the mathematical learning outcomes will increase. From the results of this calculation, it can be seen that by increasing the motivation to learn and the attention of parents to children's learning activities in mathematics, the results of student mathematics learning will be even better, and vice versa.

The sixth hypothesis test results are that there is a positive and significant relationship between the use of learning resources and parents' attention to mathematics learning outcomes, with a multiple correlation coefficient $(\mathrm{R})=0.7675$ at a significant level of $5 \%$. This can be explained through linear relationships $\hat{Y}=-33,2336+0,5423 X_{1}+0,638 X_{2}$. This means that every increase of one unit $X_{2}$ results in 0.5423 increase in $\mathrm{Y}$ and every increase in one unit $\mathrm{X}_{3}$ results in 0.638 increase in $\mathrm{Y}$, in other words, if the use of learning resources and the attention of students' parents are good, the mathematical learning outcomes will also increase. From the results of this calculation, it can be seen that by increasing the use of learning resources properly and parents 'attention to children's learning activities in mathematics, students' mathematics learning outcomes will be even better, and vice versa. 
The seventh hypothesis test result is that there is a positive and significant relationship between learning motivation, the use of learning resources and parents' attention with mathematics learning outcomes, with a multiple correlation coefficient $(r)=0.8085$ at a significant level of $5 \%$. This can be explained through linear relationships $\hat{Y}=-33,3846+0,4273 X_{1}+0,4876 X_{2}+0,2882 X_{3}$. This means that each increase of one unit $X_{1}$ results in 0.4273 increase in $Y$, every increase in one unit $X_{2}$ results in 0.4876 increase in $\mathrm{Y}$ and every increase in one unit $\mathrm{X}_{3}$ results in 0.2882 increase in $\mathrm{Y}$, in other words, if the motivation to learn, use of learning resources and attention the better the parents, the mathematical learning outcomes will increase. Student mathematics learning outcomes are influenced by learning motivation, use of learning resources and parents' attention with an effective contribution of $67.871 \%$ while $32.129 \%$ is influenced by other factors not discussed in this study.

\section{CONCLUSION}

Based on the results of research and discussion as described, several research conclusions can be drawn as follows.

1. There is a positive and significant relationship between learning motivation and mathematics learning outcomes of Grade VII students of Odd Semester MTs Negeri Godean Sleman Regency Academic Year 2015/2016. This is indicated by the test $(\mathrm{t})$, that is $t_{\text {stat }}=5,5216 ; t_{\text {table }}=1.6973$ so that $t_{\text {count }}>t_{\text {table }}$. The simple correlation coefficient ( $\mathrm{r}$ ) between learning motivation $\left(\mathrm{X}_{1}\right)$ with mathematics learning outcomes $(\mathrm{Y})$ of 0.7099 with linear regression equations $\hat{Y}=5,9704+$ $0,7431 X_{1}$.

2. There is a positive and significant relationship between the use of learning resources with mathematics learning outcomes for students of class VII Odd Semester MTs Negeri Godean Sleman Regency Academic Year 2015/2016. This is indicated by the test $(\mathrm{t})$, that is $t_{\text {count }}=$ 4,$8054 ; t_{\text {table }}=1.6973$ so that $t_{\text {count }}>t_{\text {table }}$. The simple correlation coefficient ( $\mathrm{r}$ ) between the use of learning resources $\left(\mathrm{X}_{2}\right)$ with mathematics learning outcomes $(\mathrm{Y})$ of 0.6595 with linear regression equations $\hat{Y}=-4,0393+0,8602 X_{2}$.

3. There is a positive and significant relationship between parent's attention and mathematics learning outcomes of VII grade students of Odd Semester MTs Negeri Godean Sleman Regency Academic Year $2015 / 2016$. This is indicated by the test $(\mathrm{t})$, that is $t_{\text {count }}=5,1001 ; t_{\text {table }}=1.6973$ so that $t_{\text {count }}>t_{\text {table. }}$. The simple correlation coefficient $(\mathrm{r})$ between parents' attention $\left(\mathrm{X}_{3}\right)$ with mathematics learning outcomes $(\mathrm{Y})$ of 0.6814 with linear regression equations $\hat{Y}=-14,7875+$ $0,9406 X_{3}$.

4. 4. There is a positive and significant relationship between learning motivation and the use of learning resources with mathematics learning outcomes for Grade VII students of Odd Semester MTs Negeri Godean, Sleman Regency Academic Year 2015/2016. This is indicated by the F test, that is $F_{\text {count }}=27,8937 ; F_{\text {table }}=3,33$ so that $F_{\text {count }} \geq F_{\text {table }}$. The multiple correlation coefficient $(\mathrm{R})$ of 0.8111 with a linear regression equation $\hat{Y}=-24,7388+0,5475 X_{1}+$ $0,5668 X_{2}$.

5. 5. There is a positive and significant relationship between learning motivation and parents' attention with the mathematics learning outcomes of Grade VII students of Odd Semester MTs Negeri Godean Sleman Regency Academic Year 2015/2016. This is indicated by the F test, that is $F_{\text {count }}=19,9599 ; F_{\text {table }}=3,33$ so that $F_{\text {count }} \geq F_{\text {table }}$. The multiple correlation coefficient (R) of 0.7713 with a linear regression equation $\hat{Y}=-17,0504+0,4806 X_{1}+0,5129 X_{3}$.

6. 6. There is a positive and significant relationship between the use of learning resources and parents' attention with the mathematics learning outcomes of Grade VII students of Odd Semester MTs Negeri Godean Sleman Regency Academic Year 2015/2016. This is indicated by the F test, that is $F_{\text {count }}=20,7974 ; F_{\text {table }}=3,33$ so that $F_{\text {count }} \geq F_{\text {table }}$. The multiple correlation coefficient (R) of 0.7675 with a linear regression equation $\hat{Y}=-33,2336+0,5423 X_{2}+0,6387 X_{3}$. 
7. There is a positive and significant relationship between learning motivation, the use of learning resources and parents' attention with the mathematics learning outcomes of Grade VII students of Odd Semester MTs Negeri Godean, Sleman Regency Academic Year 2015/2016. This is indicated by the $\mathrm{F}$ test, that is $F_{\text {count }}=19,716 ; F_{\text {table }}=2,95$ so that $F_{\text {count }} \geq F_{\text {table }}$. The multiple correlation coefficient $(\mathrm{R})$ of 0.8085 with linear regression equations $\hat{Y}=-33,3846+$ $0,4273 X_{1}+0,4876 X_{2}+0,2882 X_{3}$, with a double determination coefficient of 67.87 , this means that student mathematics learning outcomes are influenced by learning motivation, use of learning resources and parents' attention by $67.871 \%$ while $32.129 \%$ is influenced by other factors not discussed in this study.

\section{REFERENCES}

Sugiyono. 2012b . Statistika untuk Penelitian. Bandung : Alfabeta.

.2009a. Metode Penelitian Pendidikan (Pendekatan Kuantitatif, Kualitatif, dan R\&D). Bandung : Alfabeta.

Arikunto, Suharsimi. 2009. Dasar-Dasar Evaluasi Pendidikan. Jakarta: Bumi Aksara. 